Manjappa S. et al. / International Journal of Research in Pharmaceutical and Nano Sciences. 9(1), 2020, 7-13.

Research Article

ISSN: $2319-9563$

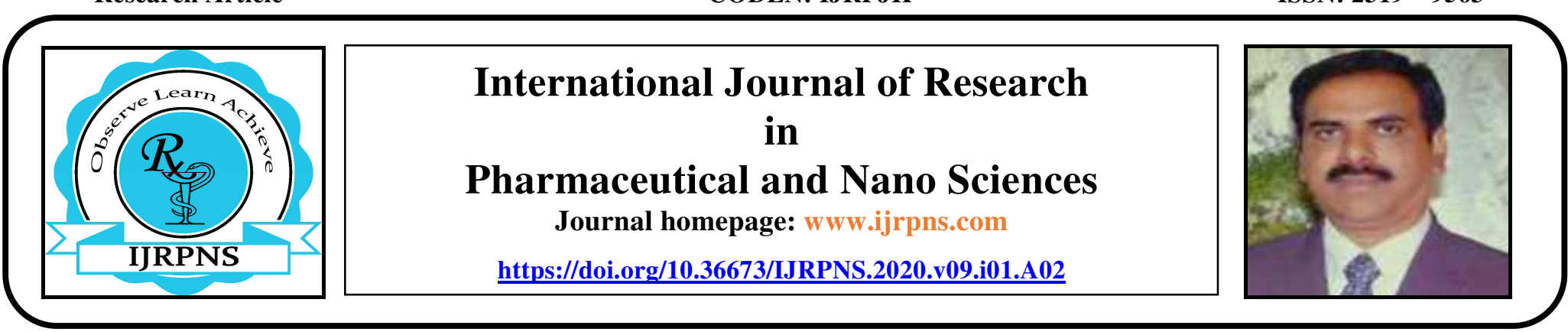

\title{
APPRAISAL OF GROUND WATER QUALITY USING GROUND WATER QUALITY INDEX NEAR JAGALUR TALUK, DAVANGERE DISTRICT, KARNATAKA STATE, INDIA
}

\author{
S. Manjappa*1, M. Ravikumar ${ }^{2}$, B. Vijay ${ }^{1}$, B. Suresh ${ }^{3}$ \\ ${ }^{1 *}$ Department of Chemistry, UBDTCE, Davangere District, Karnataka, India. \\ ${ }^{2}$ Department of Botany, Kottureshwara Degree College, Kottur, Bellary District, Karnataka, India. \\ ${ }^{3}$ Department of Civil Engineering, BIET, Davangere District, Karnataka, India.
}

\begin{abstract}
Ground water is one of the substantial fresh water resources accessible for human requirement. Early people documented the significance of water from a quantity view point. However appraisal of the quality of ground water is required for improving its potability. In the present work appraised the water quality of Jagalur taluk and its surrounding areas, which is located $51 \mathrm{~km}$ away from the Davangere city at $14.53^{\circ} \mathrm{N} 76.35^{\circ} \mathrm{E}$ of Karnataka, India. Water quality is analyzed for about 10 physico-chemical variables of 25 water samples collected from diffrent locations of 25 villages from Jagalur Taluk. The ground water samples are collected physically from the bore-wells which were nearly equal scattered all over 25 villages of Jagalur Taluk. The samples were analyzed The EC and TDS were also measured in the spot at the time of sample collected using water analysis kit (Elico-make) and fixation of dissolved oxygen was done immediately after the collection in the field by Winkler's method. Then the ground water samples were transported to the laboratory for the analysis of various physiochemical variables. The combined effect of all there variables was expressed in terms of WATER QUALITY INDEX Jagalur taluk map has been collected and analyzed. The data base obtained from water quality testing is used as characteristics to compare the quality for drinking purposes and the spatial scattering of various water quality variables. The water present in the villages like Borapura, Rangaianadurga, Gowripura and Gopalpura was found to be unfit for drinking. The conclusion of the current research may be abundent for proper decision making for policy of the treatment facilities by the establishment.
\end{abstract}

KEYWORDS

Groundwater, Water quality, Water quality index and Water quality variables.

\section{Author for Correspondence:}

Manjappa $S$,

Department of Chemistry,

UBDTCE, Davangere District, Karnataka, India.

Email: drsmubdtce@rediffmail.com

Available online: www.uptodateresearchpublication.com

\section{INTRODUCTION}

Water is an elixir of existence. Life, prosperity, and development turn around water in the whole world. The accessibility of a water supply adequateinterms of both quantity and quality is essential to human survival. Early people acknowledged the conse quence of water from a quantity view point. Civilization residential around water bodies that January - February 
Manjappa S. et al. / International Journal of Research in Pharmaceutical and Nano Sciences. 9(1), 2020, 7-13.

could sustain agriculture and transportation as well as provided drinking water. Recognition of the importance of the water quality developed more gradually ${ }^{1}$. Early humans could moderator the water quality only complete the physical sense of view, taste and odor. The mean daily ingestion of water by human is predictable to be $3.2 \%$ of the body weight. Hence, water for drinking functions must not contain harmful materials that causes adverse effects, but at the same time should be appealing lysuitable to the consumer. The water covers about $1 / 3$ of our sphere and it is said to footnote that predominantly in rural areas about $72 \%$ of the world population survive without clean water ${ }^{2,3}$.

Water is a chemical composite and may present in as olid, inaliquid and inagaseous forms. All these three habits of water are enormously functional to man, giving magnificence and comforts, in count to satisfying his basic requirements of existence. Every one of us know show significant and valuable water is. When ever, there is now at erinourtaps, we become helpless. Nolife can occur without water, since water is as crucial for life asairis. It has been estimated that two-third of human body is established of water. Water is unconditionally crucial not only for survival of human life's butals of or fauna, flora and all other existing beings. Further, it is essential that the water mandatory for the irneeds must be moral, and it should not contain unwanted foams and harmful chemical compounds and micro be sinit ${ }^{4}$.

The valuable ground-water resources are now-adays impure by varieties of man-made actions, which are unavoidably coming up in the process of improvement ${ }^{5}$. Ground waters are infected chiefly due to penetration of contaminants into the soilsublayer. Site-specific appearances such as soil type, depth of the aquifer, climate, period and the restore rate of an aquifer all encouragement the prob ability and sternness of a particular contamination incident $^{6}$.

Available online: www.uptodateresearchpublication.com

\section{STUDY AREA AND DATA COLLECTION Study area}

Karnataka state is located in the southern extending India. Jagalur is one of the Taluk headquarters, located about $48 \mathrm{Kms}$ from Davangere district (corporation city), Karnataka state. The taluk originates under granite and gnessic formation which is commonly called as "hard rock terrain". However, green pebble belt consisting of chlorite-schist, mica-schist along with clay foundations have been identified in the hard rock creations of this region.

The Jagalur Taluk Davangere district is surrounded by Haveri district at West, Bellary district at North, Chitradurga district at East and Shimoga district at South. There is no source of drinking water for the people living in this area except groundwater. Most of the people used to complain about the non-palatability of the ground water. The ground water quality is very poor in this area and hence we have under taken this project to appraise the real ground water quality. The working area location is shown in the Figure No.1.

\section{Data collection}

Ground water samples from bore wells available in $25 n$ village of Jagalur Taluk Davangere District are collected in a clean water bottle for twelve months (June 2018 to May 2019). The total number of water samples collected is 25 . Each sample was tested for water quality variables.

\section{METHODOLOGY}

Underground water samples were collected in the early morning from 9.00AM to $12.00 \mathrm{PM}$ for three days. The collected samples were conserved and analyzed for 10 variables in laboratory. The variables are $\mathrm{pH}$ ( $\mathrm{pH}$ meter), total dissolved solids (TDS) using conductivity meter, alkalinity, total hardness, calcium and chloride by titration method, nitrate using Spectrophotometer and fluoride by ion selective electrode method (APHA, 1994 and Nertan C and Rosu C., 2008).

January - February 
Manjappa S. et al. / International Journal of Research in Pharmaceutical and Nano Sciences. 9(1), 2020, 7-13.

\section{DETERMINATION OF WATER QUALITY INDEX}

Water Quality Index (WQI) is an actual helpful and resourceful method for appraising the quality of water. WQI is very helpful tool for communicate the evidence on whole quality of water since the quality of water does not depend on a one variables. There are about 11 to12 physico-chemical variables to be tested for measuring the quality of water a part from microbiological tests. To define the appropriateness of the ground-water for drinking purposes, WQI is computed adopting the following formula7. Based on the WQI values, the ground-water quality is graded as excellent, good, fair, poor and unfit for drinking needs for human.

\section{WQI = Antilog $\left[\sum W^{n} \mathbf{n}=1 \log 10 q n\right]$}

Here, $\mathrm{W}=$ Weight age factor $(\mathrm{W})$ is calculated using the following equation,

$\mathrm{W}_{\mathrm{n}}=\mathrm{K} / \mathrm{S}_{\mathrm{n}}$ and $\mathrm{K}=$ proportionality constant is imitative from, $K=\left[1 /\left(\sum_{n}{ }_{n}=11 / S i\right)\right]$

$\mathrm{S}_{\mathrm{n}}$ and $\mathrm{S}_{\mathrm{i}}$ are Indian Standard values of the water quality variables. Quality rating (q) is considered by adopting the formula,

$\mathrm{qni}=\left\{\left[\left(\mathrm{V}_{\text {actual }}-\mathrm{V}_{\text {ideal }}\right) /\left(\mathrm{V}_{\text {standard }}-\mathrm{V}_{\text {ideal }}\right)\right]^{*} 100\right\}$

Where, qni = Quality rating of it parameter for a total of water quality variables

$\mathrm{V}_{\text {actual }}=$ Value of the water quality variable obtained from laboratory study

Videal=Value of the water quality variable can be obtained from the standard tables

Videal for $\mathrm{ph}=7$ and for other variables it is equivalent to zero.

$\mathrm{V}_{\text {standard }}=\mathrm{BIS}$ standard of the water quality variable.

\section{RESULTS AND DISCUSSION}

As we have to analyze more than 25 samples for about 10 variables each the laboratory procedures are found to be cumbersome and time taking which cannot be completed within the stipulated time. The multi variable kit provides a quick, easy and in-situ measurement of water quality variables. To calibrate or to authenticate multi parameter test kit, water samples of Jagalur Taluk in all villages are tested by laboratory procedures. The results obtained were tabulated. The following Table.4 gives the comparison between the results obtained from laboratory tests. Average Water Quality Parameters and WQI of each village are given in the Table No.5 below.

\section{Water Quality Index}

The WQI of major villages in Jagalur Taluk was found to be poor. The WQI in villages like Dowlatpura was found to be excellent whereas the water quality index in villages like Bujanganagara, Narasingapura, Susheelanagara, Chikkantapura and Yashavantanagarawas found to be good. The most villages had fair water quality index and needs Treatment (Filtration and Disinfection). The water present in the villages like Taranagara, Dharmapura, Nidagurthi and Bandriwas found to be unfit for drinking ${ }^{8}$. The main reasons for this as we have observed are open discarding of solid wastes, occurrence of, quarrying areas, mis-used ponds, use of fertilizers, etc., 
Manjappa S. et al. / International Journal of Research in Pharmaceutical and Nano Sciences. 9(1), 2020, 7-13.

Table No.1: Water Quality Parameter, Their BIS Standards, and Weightings

\begin{tabular}{|c|c|c|c|}
\hline S.No & PARAMETER & STANDARD $\left(\mathbf{S n}_{\mathbf{N}} \mathbf{i} \mathbf{)}\right.$ & WEIGHTAGE(Wn) \\
\hline 1 & $\mathrm{pH}$ & 8.5 & 0.02675 \\
\hline 2 & Turbidity $(\mathrm{NTU})$ & 5.0 & 0.04547 \\
\hline 3 & Chloride $(\mathrm{mg} / \mathrm{L})$ & 250.0 & 0.00091 \\
\hline 4 & Total Hardness $(\mathrm{mg} / \mathrm{LasCaCO} 3)$ & 300.0 & 0.00076 \\
\hline 5 & Total Alkalinity $(\mathrm{mg} / \mathrm{L})$ & 200.0 & 0.00114 \\
\hline 6 & Iron $(\mathrm{mg} / \mathrm{L})$ & 0.3 & 0.75770 \\
\hline 7 & Fluoride $(\mathrm{mg} / \mathrm{L})$ & 1.5 & 0.15154 \\
\hline 8 & Nitrate(mg/L) & 45.0 & 0.00506 \\
\hline 9 & Calcium $(\mathrm{mg} / \mathrm{LasCa})$ & 75.0 & 0.00304 \\
\hline 10 & Total Dissolved Solids $(\mathrm{mg} / \mathrm{L})$ & 500.0 & 0.00043 \\
\hline
\end{tabular}

Table No.2: Water Quality Index Categories

\begin{tabular}{|c|c|c|}
\hline S.No & WATER QUALITY INDEX & NARRATIVE \\
\hline 1 & $0-25$ & Excellent \\
\hline 2 & $26-50$ & Good \\
\hline 3 & $51-75$ & Poor \\
\hline 4 & $76-100$ & Very Poor \\
\hline 5 & $>100$ & Unfit for drinking \\
\hline
\end{tabular}

Table No.3: Average Water Quality Parameters and WQI of each village

\begin{tabular}{|c|c|c|c|c|c|c|c|c|c|c|c|c|}
\hline$\stackrel{i}{i}$ & $\begin{array}{l}\text { NAME OF THE } \\
\text { VILLAGE }\end{array}$ & pH & 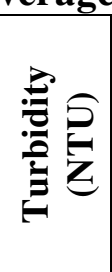 & 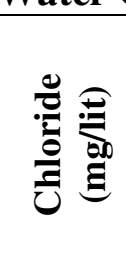 & 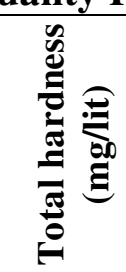 & 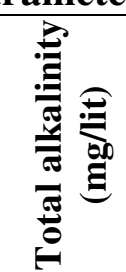 & 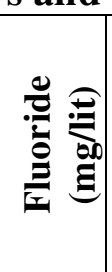 & 㤩 & 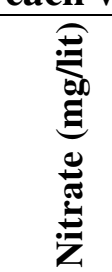 & 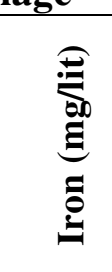 & 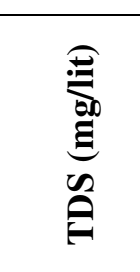 & $\bar{z}$ \\
\hline 1 & li & 7.62 & 4.75 & 560.8 & 331.5 & 278.5 & 1.20 & 127.5 & 106.2 & 0.080 & 509.0 & 68.91 \\
\hline 2 & Madamı & 7.00 & 5.00 & 762.3 & 475.0 & 325.0 & 2.30 & 90.0 & 65.0 & 0.090 & 13.0 & 57.09 \\
\hline 3 & Chada & 7.25 & 2.50 & 490.2 & 356.2 & 287.5 & 1.10 & 127.5 & 48.7 & 0.070 & 422.0 & 56.34 \\
\hline 4 & & 7.16 & 3.33 & 884.0 & 500.0 & 533.3 & 1.75 & 90.0 & 40.0 & 0.085 & 917.0 & 24.26 \\
\hline 5 & Santher & 7.50 & 0.00 & 719.9 & 431.2 & 505.7 & 1.64 & 82.5 & 25.0 & 0.075 & 795.0 & 44.11 \\
\hline 6 & Lam & 7.50 & 5.83 & 860.3 & 479.1 & 509.6 & 1.81 & 108.3 & 37.5 & 0.068 & 891.0 & 52.54 \\
\hline 7 & re & 7.125 & 3.75 & 963.0 & 550.0 & 531.5 & 1.78 & 80.0 & 30.0 & 0.092 & 1207.0 & 33.63 \\
\hline 8 & kere & 7.15 & 3.75 & 887.4 & 575.0 & 531.5 & 1.21 & 147.5 & 58.7 & 0.060 & 1288.0 & 54.54 \\
\hline 9 & 1010 & 7. & 8.75 & 1214.0 & 600.0 & 500.0 & 2.90 & 180.0 & 102.5 & 0.080 & 1500.0 & 53.15 \\
\hline 10 & alli & 7.16 & 5.00 & 1234.0 & 458.3 & 591.6 & 1.72 & 93.3 & 31.6 & 0.095 & 1500.0 & 69.95 \\
\hline 11 & Ajjabom & 7.16 & 5.00 & 217.0 & 400.0 & 225.0 & 1.55 & 86.66 & 28.3 & 0.055 & 417.0 & 17.89 \\
\hline 12 & Settig & 7.25 & 6.25 & 927.0 & 600.0 & 525.0 & 1.42 & 130.0 & 53.5 & 0.050 & 1302.0 & 54.09 \\
\hline 13 & Do & 7.83 & 3.00 & 920.7 & 500.0 & 566.6 & 1.69 & 90.0 & 51.6 & 0.015 & 1304.0 & 116.55 \\
\hline 14 & allenahalli & 7.166 & 0.00 & 943.0 & 550.0 & 583.3 & 1.58 & 106.7 & 66.6 & 0.065 & 1152.0 & 50.73 \\
\hline 15 & $11 \mathrm{i}$ & 7.375 & 6.25 & 860.8 & 506.2 & 562.5 & 1.10 & 100.0 & 72.5 & 0.095 & 1261.0 & 53.12 \\
\hline 16 & Vaddarahatti & 7.75 & 3.75 & 836.2 & 475.0 & 537.5 & 1.75 & 100.0 & 30.0 & 0.080 & 1149.0 & 58.93 \\
\hline 17 & & 7.25 & 2.50 & 558.4 & 375.0 & 400.0 & 1.31 & 75.0 & 27.5 & 0.083 & 585.0 & 34.62 \\
\hline 18 & Fort (in ruins) & 7.50 & 6.66 & 878.6 & 516.6 & 525.0 & 1.25 & 100.0 & 78.3 & 0.090 & 1229.0 & 66.76 \\
\hline
\end{tabular}

Available online: www.uptodateresearchpublication.com January - February 
Manjappa S. et al. / International Journal of Research in Pharmaceutical and Nano Sciences. 9(1), 2020, 7-13.

\begin{tabular}{|c|c|c|c|c|c|c|c|c|c|c|c|c|}
\hline 19 & Magadi & 7.80 & 2.00 & 788.8 & 425.0 & 435.0 & 2.15 & 84.0 & 30.0 & 0.015 & 1119.0 & 54.76 \\
\hline 20 & Rangaianadurga & 7.00 & 5.00 & 1312.0 & 760.0 & 575.0 & 1.32 & 173.3 & 38.3 & 0.095 & 1500.0 & 159.5 \\
\hline 21 & Venkatapur & 7.16 & 2.66 & 1123.0 & 860.0 & 541.6 & 1.40 & 136.7 & 51.6 & 0.100 & 1500.0 & 34.06 \\
\hline 22 & Gopalpura & 8.50 & 5.00 & 690.5 & 387.5 & 430.5 & 1.80 & 90.0 & 55.0 & 0.093 & 735.0 & 149.7 \\
\hline 23 & Thumbinakatte & 7.00 & 5.00 & 1214.0 & 860.0 & 575.0 & 2.20 & 120.0 & 0.0 & 0.104 & 1500.0 & 52.65 \\
\hline 24 & Lakkampura & 7.83 & 2.66 & 765.4 & 483.3 & 533.3 & 2.40 & 113.3 & 26.6 & 0.108 & 983.0 & 63.19 \\
\hline 25 & Gowripura & 7.16 & 3.66 & 855.7 & 450.0 & 600.0 & 2.50 & 146.7 & 43.3 & 0.045 & 1214.0 & 134.49 \\
\hline
\end{tabular}

Table No.4: Water Quality Index value of ground water samples during the study period

\begin{tabular}{|c|c|c|c|}
\hline Code & Village & WQI (Qi) & Composition of variables \\
\hline 1 & Laxmipura & 68.91 & $\mathrm{Ca}-\mathrm{F}-\mathrm{NO}_{3}-\mathrm{Cl}$ \\
\hline 2 & Nandihalli & 57.09 & $\mathrm{NO}_{3}-\mathrm{F}$ \\
\hline 3 & Tumati & 56.34 & $\mathrm{Ca}-\mathrm{NO}_{3}-\mathrm{Cl}-\mathrm{NO}_{3}$ \\
\hline 4 & Bujanganagara & 24.26 & $\mathrm{Ca}-\mathrm{F}-\mathrm{NO}_{3}-\mathrm{Cl}$ \\
\hline 5 & Narasingapura & 44.11 & $\mathrm{Ca}-\mathrm{F}-\mathrm{Cl}-\mathrm{NO}_{3}$ \\
\hline 6 & Ranajithpura & 52.54 & $\mathrm{Ca}-\mathrm{F}-\mathrm{Cl}-\mathrm{NO}_{3}$ \\
\hline 7 & Susheelanagara & 33.63 & $\mathrm{Fa}-\mathrm{Ca}-\mathrm{Cl}$ \\
\hline 8 & Siddapura & 54.54 & $\mathrm{Ca}-\mathrm{F}-\mathrm{NO}_{3}-\mathrm{Cl}$ \\
\hline 9 & Jaisingpura & 53.15 & $\mathrm{~F}-\mathrm{Ca}-\mathrm{NO}_{3}-\mathrm{Cl}$ \\
\hline 10 & Venkatagiri & 69.95 & $\mathrm{Ca}-\mathrm{NO}_{3}-\mathrm{Cl}$ \\
\hline 11 & Dowlatpura & 17.89 & $\mathrm{Ca}-\mathrm{Cl}-\mathrm{F}$ \\
\hline 12 & D.Thimmalapura & 54.09 & $\mathrm{Ca}-\mathrm{NO}_{3}-\mathrm{Cl}$ \\
\hline 13 & Taranagara & 116.55 & $\mathrm{Ca}-\mathrm{Cl}$ \\
\hline 14 & Muraripura & 50.73 & $\mathrm{Ca}-\mathrm{NO}_{3}$ \\
\hline 15 & V-Nagalpura & 53.12 & $\mathrm{Ca}-\mathrm{NO}_{3}-\mathrm{Cl}$ \\
\hline 16 & Taluru & 58.93 & $\mathrm{Ca}-\mathrm{Cl}-\mathrm{NO}_{3}$ \\
\hline 17 & Chikkantapura & 34.62 & $\mathrm{Ca}-\mathrm{NO}_{3}-\mathrm{Cl}$ \\
\hline 18 & S-Basapura & 66.76 & $\mathrm{Ca}-\mathrm{Cl}$ \\
\hline 19 & Kurekuppa & 54.76 & $\mathrm{Ca}-\mathrm{NO}_{3}-\mathrm{Cl}$ \\
\hline 20 & Dharmapura & 159.5 & $\mathrm{Ca}-\mathrm{Cl}$ \\
\hline 21 & Yashavantanagara & 34.06 & $\mathrm{Ca}-\mathrm{Cl}-\mathrm{NO}_{3}$ \\
\hline 22 & Nidagurthi & 149.7 & $\mathrm{Ca}-\mathrm{NO}_{3}-\mathrm{Cl}$ \\
\hline 23 & Mallapura & 52.65 & $\mathrm{Ca}-\mathrm{Cl}-\mathrm{NO}_{3}$ \\
\hline 24 & Katinakamba & 63.19 & $\mathrm{Cg}-\mathrm{Cl}-\mathrm{NO}_{3}$ \\
\hline 25 & Bandri & 134.49 & $\mathrm{Ca}-\mathrm{Cl}-\mathrm{NO}_{3}$ \\
\hline
\end{tabular}

Table No.5: WQI and corresponding class and status of water quality

\begin{tabular}{|c|c|c|c|c|}
\hline S.No & Class & WQI Value & Status of Water & $\begin{array}{c}\text { Ground Water } \\
\text { Samples }\end{array}$ \\
\hline 1 & Excellent & $0-24$ & Pristine Quality & 01 \\
\hline 2 & Good & $25-49$ & Acceptable & 05 \\
\hline 3 & Fair & $50-74$ & Needs Treatment (Filtration and Disinfection) & 15 \\
\hline 4 & Poor & $75-94$ & Special Treatment (Special Treatment) & - Nil- \\
\hline 5 & Heavily Polluted & $95-100$ & Unsuitable for All Purposes & 04 \\
\hline
\end{tabular}

Available online: www.uptodateresearchpublication.com January - February 


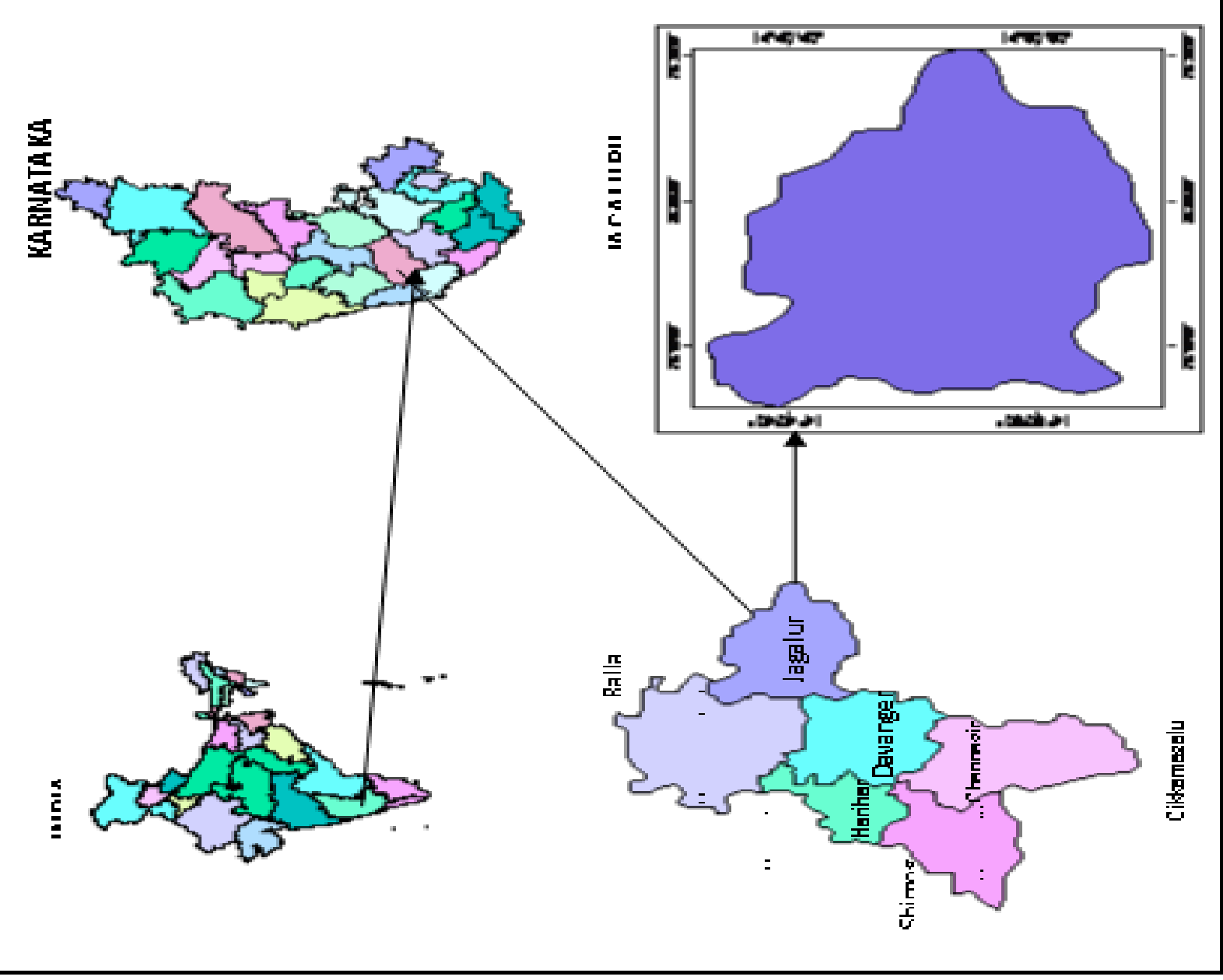

Figure No.1: Location of the study area

\section{CONCLUSION}

It is essential that the consuming water must be pure. However, the complete pure water is not originated in nature. Even the rain water completely pure at the prompt it is created becomes polluted since as it permits through environment it dissolves. definite gases, traces of minerals, sprinkle, bacteria, and numerous other substances, Hence, it is crucial to establish the quality of water accessible from the various sources to whether the water is drinkable or not. So to recognize the portability circumstances numerous variables like $\mathrm{pH}$, Chloride, Turbidity, Total Hardness, Total Alkalinity, Iron, and fluoride, Nitrate, Calcium and Total dissolved solids were examined for the study region and

Available online: www.uptodateresearchpublication.com tabulated. Water quality index calculated, the final productivity has given in the symbolic demonstration of ground water quality appropriate or inappropriate for consumption purposes in the region under work. Out of 25 villages out off only one village ground-water comes under 'excellent' category and five village ground water 'good' category. In four villages, the ground water is unfit for drinking and in remaining villages it is in fair condition as per WQI. The analytical result exposes that the ground- water of the area requests some degree of treatment before utilization. The continuous monitoring of groundwater is mandatory in the district to protect water in opportunity from any possible pollution due to growing industrialization and farming practices.

January - February 
Manjappa S. et al. / International Journal of Research in Pharmaceutical and Nano Sciences. 9(1), 2020, 7-13.

\section{ACKNOWLEDGEMENT}

The authors wish to express their sincere gratitude to Department of Chemistry, UBDTCE, Davangere District, Karnataka, India for providing necessary facilities to carry out this research work.

\section{CONFLICT OF INTEREST}

We declare that we have no conflict of interest.

\section{REFERENCES}

1. Subba Rao N. Studies on the water quality index in hard rock terrain of Guntur district, Andhra Pradesh, India. National Seminar on Hydrology of Precambrian Terrains and hard rock areas, 1997, 129-134.

2. Tiwari T N, Mishra M A. A preliminary assignment of water quality index of major Indian rivers, Indian J Environ Proc, 5(4), 1985, 276-279.

3. Ferry Ledi Tjandra, Akihiko Kondhoh, Mohammed Aslam M A. A Conceptual Database Design for Hydrology Using GIS, Proceedings of Asia Pacific Association of Hydrology and Water Resources, Kyoto, Japan. 2003, 13-15,

4. Burrough P A, Mc Donnell. Principles of Geographical Information Systems, Oxford University Press, Oxford, 1998, 333.

5. Census of India. Director of Census Operations. District Census Handling of Andhra Pradesh. 2001.

6. Abassi S A. Water Quality Indices, State-ofthe art, J.IPHE, 1999, 1.

7. Pradhan S K, Dipika Patnaik, Rout S P. Water quality index for the groundwater in and around a phosphatic fertilizer plant, Indian Journal of Environmental Protection, 21(4), 2001, 355-358.
8. Thotappaiah T M, Suresh T, Manjappa S and Suresh B. Seasonal dissimilarity of trace metals in Groundwater Quality of Sandur Taluk, Bellary District (India) by Descriptive Analysis and Similarity Index, International Journal of Research in Engineering and Advanced Technology, 4(4), 2016, 8-14.

Please cite this article in press as: Manjappa $\mathrm{S}$ et al. Appraisal of ground water quality using ground water quality index near Jagalur Taluk Davangere District, Karnataka State, India, International Journal of Research in Pharmaceutical and Nano Sciences, 9(1), 2020, 7-13. 